\title{
The complexities of malaria disease manifestations with a focus on asymptomatic malaria
}

Dolie D Laishram ${ }^{1,3}$, Patrick L Sutton ${ }^{2}$, Nutan Nanda ${ }^{1}$, Vijay L Sharma ${ }^{3}$, Ranbir C Sobti ${ }^{4}$, Jane M Carlton ${ }^{2^{*}}$ and Hema Joshi ${ }^{1}$

\begin{abstract}
Malaria is a serious parasitic disease in the developing world, causing high morbidity and mortality. The pathogenesis of malaria is complex, and the clinical presentation of disease ranges from severe and complicated, to mild and uncomplicated, to asymptomatic malaria. Despite a wealth of studies on the clinical severity of disease, asymptomatic malaria infections are still poorly understood. Asymptomatic malaria remains a challenge for malaria control programs as it significantly influences transmission dynamics. A thorough understanding of the interaction between hosts and parasites in the development of different clinical outcomes is required. In this review, the problems and obstacles to the study and control of asymptomatic malaria are discussed. The human and parasite factors associated with differential clinical outcomes are described and the management and treatment strategies for the control of the disease are outlined. Further, the crucial gaps in the knowledge of asymptomatic malaria that should be the focus of future research towards development of more effective malaria control strategies are highlighted.

Keywords: Asymptomatic malaria, Host factors, Parasite factors, Transmission dynamics
\end{abstract}

\section{Background}

Malaria remains a serious global health burden, with an annual incidence of 247 million cases and nearly one million deaths, most of which afflict children living in Africa [1]. Of the four human malaria parasite species, Plasmodium falciparum is reported to cause the highest morbidity and mortality. Young children with naïve immune systems [2] and pregnant women with potentially compromised immune systems are particularly vulnerable to this disease and so are considered to be the highest risk populations for malaria-related deaths. $P$. falciparum disease severity ranges from severe and complicated, to mild and uncomplicated, to asymptomatic $[3,4]$. Understanding the impact of $P$. falciparum on the human host across this range is critical for learning how to improve the management of the disease.

\footnotetext{
* Correspondence: jane.carlton@nyu.edu

${ }^{2}$ Center for Genomics and Systems Biology, Department of Biology, New

York University, 12 Waverly Place, New York, NY 10003, USA

Full list of author information is available at the end of the article
}

Generally, severe or complicated malaria has been at the core of epidemiological studies because it is the principal cause of malaria-related deaths. Researchers and clinicians have established diagnostic criteria based on the clinical manifestations upon disease onset, which has aided in forming an integrated approach to improving the management and treatment of severe malaria. Severe malaria is now defined by at least one of the following clinical manifestations: unrousable coma (caused by cerebral malaria), convulsions, malarial anaemia, haemoglobinuria, hypoglycaemia, metabolic acidosis (associated with respiratory distress), acute pulmonary oedema, acute renal failure, jaundice, circulatory collapse, hyperparasitaemia, high fever electrolyte disturbance, and/or spontaneous bleeding [4]. In areas of high transmission, this full spectrum of clinical severity is primarily observed in children; severe malaria is negatively correlated with age due to the development of exposure-related immunity in adults [5,6]. This is further supported by finding that frequent exposure to $P$. falciparum malaria in high transmission regions typically
C Biomed Central

() 2012 Laishram et al; licensee BioMed Central Ltd. This is an Open Access article distributed under the terms of the Creative Commons Attribution License (http://creativecommons.org/licenses/by/2.0), which permits unrestricted use, distribution, and reproduction in any medium, provided the original work is properly cited. 
reduces the period of risk for severe malaria, while in lower transmission regions infrequent exposure extends this period of risk [5].

In contrast, individuals with mild or uncomplicated malaria typically present clinically with fever and perhaps one or more of the following symptoms: chills and sweats, headache, vomiting, watery diarrhea, anaemia, jaundice, and swelling of the spleen (splenomegaly), but do not generally have any of the features identified in severe or complicated malaria [4]. If properly diagnosed and treated, recovery success is high for patients with uncomplicated malaria (reviewed in ref [6]). Uncomplicated malaria also occurs in endemic areas and is likely associated with the development of some exposurerelated immunity. For example, Gupta et al. [7] reported the development of clinical immunity to uncomplicated malaria after only one or two infective bites, highlighting the potential importance of strain-specific immunity.

Diagnosing asymptomatic malaria is not as straightforward due to the obvious lack of clinical manifestations and often subpatent (undetectable by microscopy) level of parasites [8]. Asymptomatic malaria is prevalent in malaria endemic regions and has become a serious cause for concern as efforts are increasing towards eliminating the parasite [9]. Particularly, subpatent malaria is still transmissible and will complicate elimination of malaria in high transmission regions. For example, a study in Senegal suggested that more than $90 \%$ of exposed individuals are likely infected with chronic asymptomatic malaria [8], a situation in which the majority of this population can then inadvertently act as a reservoir for malaria transmission.

For more than two decades, researchers have investigated the development of two types of immunity which may result in asymptomatic malaria: 1) an anti-disease immunity that allows one to carry parasite loads without symptoms; and 2) an anti-parasite immunity that may be responsible for the suppression of parasite loads after a certain age, which is likely a factor of exposure-related clinical immunity [10-12]. Interestingly, asymptomatic malaria is not only limited to regions of high transmission where exposure-related immunity is expected to develop; it has also been reported in the low transmission Amazonian regions of Peru, Brazil, and Columbia and also the Solomon Islands [13-21]. Exposure-related immunity may be achieved much earlier in life for individuals who live in low transmission regions due to predictably low parasite genetic diversity and few overlapping infections.

Few reports are available on the study of asymptomatic malaria caused by species other than $P$. falciparum. However, like asymptomatic $P$. falciparum, asymptomatic Plasmodium vivax malaria has been reported in a range of endemic settings. For example, the low transmission setting of Temotu Province, Solomon Islands [20] and the highly endemic malaria area of Rio Negro in the Amazon State, Brazil [22] both report significant presence of asymptomatic $P$. vivax. Another Amazonia study reports that the prevalence of "symptomless" falciparum and vivax malaria infections are 4-5 times higher than the symptomatic ones, with a significant correlation of "symptomless" malaria with older age groups [21]. Unfortunately, the reports above were limited to general prevalence surveys, without additional molecular analyses.

Though rare, cases of Plasmodium malariae and Plasmodium ovale asymptomatic infection have also reported. A case report of transfusion-transmitted $P$. malariae infection from an asymptomatic donor [23] suggests that $P$. malariae can be harbored asymptomatically. Supporting this, another study also reported a case of malaria in a Grecian woman due to P. malariae whose illness was reactivated after decades of latency [24]. Infection with $P$. ovale can also be asymptomatic [25]. However, these studies are mostly case reports and extensive longitudinal studies are lacking. Therefore, this review is focused on asymptomatic malaria due to P. falciparum.

The purpose of this review is to: (1) critically examine how asymptomatic falciparum malaria is defined; (2) describe potential relationships to transmission dynamics; (3) speculate on the potential roles of putatively important parasite genes; (4) review human genes that may contribute to susceptibility or resistance to infection; (5) discuss the management and treatment of asymptomatic malaria; and (6) discuss the gaps in knowledge and highlight areas of future research.

\section{The problem of defining asymptomatic malaria}

A major obstacle in the study of asymptomatic malaria is the lack of standard diagnostic criteria. For example, infected individuals may be in a pre-symptomatic period with parasitaemia, and present with clinical manifestations at a subsequent date [26]. Alternately, studies that do not incorporate thorough clinical history surveys may not capture individuals that may have experienced symptoms for a brief period and then taken medication that suppressed parasitaemia and symptoms. The most widely-used criteria for diagnosis of asymptomatic malaria are presence of parasites in peripheral thick blood smears, an axillary temperature $<37.5^{\circ} \mathrm{C}$, and an absence of malaria-related symptoms [27-30]. Some studies do include other criteria, such as longitudinal follow-up and parasite quantification. Longitudinal followup is particularly important for differentiating between infections that appear asymptomatic at time of detection, but may become symptomatic after the initial detection [19-33]. Quantifying parasitaemia, rather than 
noting presence or absence of parasites, may also be an important consideration when diagnosing asymptomatic malaria. However, a universally standard parasite threshold for classifying an infection as asymptomatic has yet to be defined, as different studies use variable cut-off levels for parasite density [31-33]. Though the use of species-specific PCR possible is not always available in the field, or even perhaps practical for testing infections that are negative by microscopy, it is a powerful tool for finding asymptomatic malaria within a population. For example, Bottius et al. [8,34-36] found that as many as two-thirds of the microscopy-negative patients had subpatent levels of parasites determined by diagnostic PCR, indicating that almost the entire population was chronically infected with asymptomatic malaria. Examples of the varied diagnostic criteria used to classify malaria as asymptomatic by several different studies is presented in Table 1. For a more comprehensive list, see Additional file 1.

\section{Transmission dynamics and asymptomatic malaria} Infection prevalence

The transmission dynamics of malaria are complex. Even in endemic areas, transmission is not consistently stable; rather, it can be patchy and dependent on factors such as climate, the location of mosquito breeding sites, and areas of clustered human habitations, which serve as reservoirs of parasites for mosquito infection $[39,40]$. Asymptomatic infections often go undetected and untreated, resulting in a major source of gametocytes for local mosquito vectors [14]. Even in conditions where the possibility of re-infection is excluded, P. falciparum infection has been shown to persist asymptomatically in semi-immune individuals for more than 18 months [41]. Asymptomatic P. falciparum infections can also persist inter-seasonally in regions with seasonal transmission [42]. For example, even though the incidence of clinical malaria in Senegal is significantly lower during the dry season, a considerable proportion of the population remain parasitaemic throughout the year $[29,43,44]$. This reaffirms that malaria transmission can persist in areas where symptomatic cases have been monitored and treated. This model has driven presumptive intermittent anti-malarial treatment strategies for the treatment of asymptomatic individuals, regardless of their infection status, to reduce the disease burden.

In areas with annual malaria transmission, asymptomatic $P$. falciparum parasitaemia is common among immune inhabitants $[45,46]$ and a large proportion of individuals always harbor malaria parasites without any associated clinical symptoms [47]. A positive correlation between high transmission and high asymptomatic

Table 1 A wide range of diagnostic criteria is used for defining malaria patients as asymptomatic

\begin{tabular}{|c|c|c|c|c|}
\hline $\begin{array}{l}\text { Country } \\
\text { and Year }\end{array}$ & Criteria used for identifying asymptomatic malaria cases & $\begin{array}{l}\text { Study } \\
\text { subjects, } \\
\text { sample size }\end{array}$ & Follow-up protocol and duration & Ref. \\
\hline \multicolumn{5}{|c|}{ Africa } \\
\hline $\begin{array}{l}\text { Gabon, } \\
2003\end{array}$ & $\begin{array}{l}\text { No clinical symptoms of malaria with a } P \text {. falciparum positive } \\
\text { blood smear, asymptomatic for at least } 5 \text { days during follow-up. }\end{array}$ & $\begin{array}{l}\text { Children } \\
6 \text { months to } \\
10 \text { years, } N \\
=60\end{array}$ & $\begin{array}{l}\text { Examined once daily for } 7 \text { days thereafter, once } \\
\text { every } 2 \text { days }\end{array}$ & {$[37]$} \\
\hline $\begin{array}{l}\text { Tanzania, } \\
2006\end{array}$ & $\begin{array}{l}\text { Presence of } P \text {. falciparum on blood smear, axillary temperature of } \\
<37.5^{\circ} \mathrm{C} \text {, and no other symptoms or signs of malaria }\end{array}$ & $\begin{array}{l}\text { Children } \\
4-59 \text { months, } \\
\mathrm{N}=127\end{array}$ & No follow-up. & [33] \\
\hline \multicolumn{5}{|c|}{ South America } \\
\hline $\begin{array}{l}\text { Brazilian } \\
\text { Amazon, } \\
2002\end{array}$ & $\begin{array}{l}\text { Individuals positive by microscopy, and/or positive by PCR; and } \\
\text { individuals negative by microscopy that subsequently became } \\
\text { positive by PCR. }\end{array}$ & $\begin{array}{l}\text { All age } \\
\text { groups, } \\
N=172\end{array}$ & Follow-up to day 10 and 60. & [21] \\
\hline $\begin{array}{l}\text { Colombia, } \\
2008\end{array}$ & $\begin{array}{l}\text { Presence of microscopic asexual parasite stages of } P \text {. falciparum, } \\
P \text {. vivax or } P \text {. malariae or of mixed infections in blood, which } \\
\text { persisted for at least two weeks without causing any symptoms, } \\
\text { or as the detection of parasite DNA by PCR on day } 0 \text { in people } \\
\text { who remained asymptomatic during the follow-up period. }\end{array}$ & $\begin{array}{l}\text { Individuals } \\
2-78 \text { years, } \\
\mathrm{N}=21\end{array}$ & Follow-up on days 14 and 28. & [19] \\
\hline \multicolumn{5}{|c|}{ Asia } \\
\hline $\begin{array}{l}\text { Papua, } \\
2003\end{array}$ & $\begin{array}{l}\text { No fever history or treatment for malaria within the past week, no } \\
\text { clinical evidence of malaria or other infection, no diarrhea, and no } \\
\text { current pregnancy but both P. falciparum and P. vivax positive } \\
\text { individuals }\end{array}$ & $\begin{array}{l}\text { Adults } \\
>16 \text { years, } \\
\mathrm{N}=105\end{array}$ & $\begin{array}{l}\text { Supervised overnight at local health center. A } \\
\text { third axillary temperature was recorded the } \\
\text { following morning. }\end{array}$ & {$[38]$} \\
\hline $\begin{array}{l}\text { Indonesia, } \\
2010\end{array}$ & $\begin{array}{l}\text { Presence of asexual } P \text {. falciparum or } P \text {. vivax parasitemia in the } \\
\text { absence of fever (temperature } \leq 37.9^{\circ} \mathrm{C} \text { ) and of clinical signs or } \\
\text { symptoms suggestive for malaria or another infectious disease. }\end{array}$ & $\begin{array}{l}\text { Children } \\
5-15 \text { years, } \\
N=381\end{array}$ & No follow-up. & [27] \\
\hline
\end{tabular}

A more comprehensive list of studies is given in Additional file 1 
prevalence has been reported in Nigeria, Senegal, Gabon and Amazonian regions of Brazil [8,34-36]. Similarly, an increase in the prevalence of asymptomatic vivax malaria has been noted in high transmission regions, including Thailand, Sri Lanka, and Brazil $[48,49]$. High prevalence rates of asymptomatic malaria within areas of high transmission might be due to exposure-related immunity. Exposure-related immunity occurs when individuals who are frequently exposed to parasites for long periods of time eventually develop immunological memory that suppresses infection. Paradoxically, asymptomatic malaria has also been reported in low transmission areas [15-21]. Two studies in the low transmission Peruvian Amazon demonstrated that high parasite exposure is not necessary for the development of B-cell memory or long-lasting antibody titres [50,51]. Though exposure is thought to help maintain immunological memory, other factors besides the transmission intensity may be associated with the prevalence of asymptomatic malaria within different regions.

\section{Mosquito infectivity}

The production of gametocytes within an infected human host is essential for transmitting the parasite to the mosquito. Understanding the variables that are involved in gametocyte production within the human host, such as the host immune response to parasites, anti-malarial drug treatment, and parasite genetic diversity, and correlating these with the presence or absence of symptoms, is layered with complexity. For example, some studies have indicated that the quantity of gametocytes may impact the level of mosquito infectivity [52]; however, asymptomatic carriers of sub-microscopic gametocyte densities are also infectious to the mosquito host, as found in some high transmission regions $[52,53]$. It seems that the quality, not the quantity, of gametocytes may be more important for infectivity [53-59]. Anti-malarial drug treatment has been shown to negatively impact gametocyte quality, by reducing gametocyte infectivity upon a blood meal [60]. In turn, this complicates controlled investigations of disease severity and gametocyte infectivity of the mosquito host, since more often than not, epidemiologists rely on association studies between gametocyte density or gametocyte ratios and disease severity to extrapolate a possible relationship.

There is evidence that patients with severe anaemia have higher levels of gametocytes [61], which may be the result of environmental cues released in the blood upon parasite-induced haemolysis, or alternatively may represent an artificial inflation due to the decreased number of circulating red blood cells. An earlier study also provided the evidence of this important relationship between the development of patent P. falciparum gametocytaemia and transmission potential [62]. The study suggested that the sexual stages are not pyrogenic and are commonly seen in subjects without fever, in whom the asexual parasitaemia has fallen below the pyrogenic threshold. This is supported by finding in their study that patients who were afebrile and presented with a low asexual parasitaemia were 2.7 times more likely to present with a patent gametocytaemia compared to those without both of these factors. Once these sexual stages have been formed, they are harbored and may persist for up to three weeks, imparting a persistent ability to infect mosquitoes [63,64].

A study in Thailand investigating mosquito infectivity differences between febrile and asymptomatic patients reported that febrile patients were more infective than asymptomatic individuals to mosquito hosts [65]. This was recapitulated in a study in Amazonian natives, which reported that highly parasitaemic, symptomatic patients were more infective to mosquitoes than asymptomatic patients with submicroscopic parasitaemia [14]. However, the authors reported that asymptomatic infections were 4-5 times more prevalent and infective for longer periods of time post-treatment. In contrast, Gouagna et al. reported that parasites from asymptomatic individuals in an endemic region of western Kenya were more infective to mosquitoes than parasites from symptomatic individuals. The authors concluded that this was a function of both the greater gametocyte abundance in asymptomatic individuals and a higher quality of infectious gametocytes [66,67].

These observations of asymptomatic malaria in low and high endemic areas highlight the importance of carrying out active surveys for the identification of asymptomatic carriers. The treatment of the infective parasite reservoir of asymptomatic individuals may be an important intervention strategy, and if this reservoir is greatly reduced it will provide a positive impact on the intervention of disease transmission.

\section{Role of the malaria parasite in asymptomatic malaria}

It is not clear why some P. falciparum infections are symptomatic while others are asymptomatic, but parasite factors are likely to be involved [68]. Malaria parasites influence disease outcome through factors that include parasite density, rosetting and sequestration, toxin production, and genetic diversity including expression of virulence and immune evasion genes such as the var (variant antigen receptor) gene family.

\section{Parasite density}

The precise relationship between parasite density and disease severity remains unclear, as the density of sequestered parasites and circulating parasites varies 
greatly depending upon the stage and synchronicity of the infection [69]. In general, high parasitaemia has been associated with increased disease severity; however, this is not always the case as peripheral parasitaemia does not always accurately reflect the number of parasites due to sequestration. For example, Silamut et al. reported cerebral malaria as the cause of death in aparasitaemic individuals in autopsies following effective antimalarial treatment [70]. A study in the Solomon Islands showed that both $P$. vivax- and P. falciparum-infected asymptomatic individuals tend to have low and submicroscopic parasite densities [20]. Another study suggested the association of asymptomatic parasitaemia of higher parasite density with a higher risk of symptomatic malaria [71].

A study investigating the relationship that parasite density has on platelet count showed that malariainfected children with thrombocytopenia (decreased platelet count) were younger, had higher parasitaemia, lower hemoglobin levels, an increased mean platelet volume, and exhibited platelet aggregation [72]. Similarly, a cross-sectional study on Nigerian children with asymptomatic malaria showed that malaria parasites cause a significant reduction in platelet counts with more pronounced reduction in children under 5 years of age [73]. Therefore, thrombocytopenia is not only a feature exhibited by acute malaria, but also a potentially useful indicator for monitoring asymptomatic children in high transmission areas.

\section{Strain diversity}

Various studies have investigated the genetic diversity of $P$. falciparum and its association with the development of clinical symptoms. There is strong evidence that immunity to malaria is specific to the particular strain eliciting the host response, enabling an individual to resist infection by that particular strain, but not by heterologous ones; this has been termed 'strain-specific immunity' [74-76]. The development of strain-specific immunity might then be somewhat responsible for decreased disease severity, including asymptomatic malaria, in populations where exposure is moderate to high.

Other studies have sparked an investigation of some symptom-specific molecular characteristics based on polymorphisms of surface antigens that have been identified in isolates collected from asymptomatic, uncomplicated, and severe malaria cases across various geographic regions [77-79] (see Additional file 2). Such polymorphic surface antigens include the merozoite surface protein (MSP) family, apical membrane antigen 1 (AMA1), erythrocyte binding antigen-175 (EBA-175), and knob-associated histidine rich protein (KAHRP). Specific antigenic polymorphisms may allow the parasite to evade the immune response in patients with chronic infection and thus it may lead to their survival in the human host until transmission becomes possible.

\section{Merozoite surface proteins}

Several studies have investigated the association of $m s p$ 1 and $m s p-2$ with clinical severity of disease. For example, a study conducted to examine the relationship between the genetic diversity of $m s p-1$ block 2 of $P$. falciparum and clinical severity of malaria in Nigerian children showed that the presence of K1 and MAD20 alleles were significantly associated with asymptomatic malaria and consequently reduced the risk of developing symptomatic disease [80]. Yet, it is possible that frequency of exposure to these allelic families may also be a factor. Ariey et al. [81] found that the association of a specific $m s p$ - 1 allele (K1) with a specific var gene (var$D$ ) was overrepresented among patients with severe compared to mild disease, and this genotype combination was consistently observed in the most severe clinical cases. However, investigations of genotype associations with disease severity need to be expanded to include all categories of disease, including asymptomatic malaria. Further, genetic diversity should be longitudinally monitored to ensure that such clinical associations are maintained and not biased by cross-sectional selection of isolates.

There are conflicting reports regarding the differential distribution of alleles within particular genes (such as $m s p-2)$ according to clinical status $[82,83]$. The FC27like genotype of $m s p-2$ was shown to be twice as likely to be found in symptomatic cases than in asymptomatic cases [83], providing evidence that specific variants of $m s p-2$ may be associated with the morbidity of malaria. A similar association was reported in Papua New Guinea, where the FC27 allele was linked to increased disease severity, however, this study did not consider asymptomatic cases [84]. Conversely, another study reported that there was no association between FC27 or 3D7 alleles of $m s p-2$ and malaria symptoms [85]. However, further longitudinal studies in different geographical settings with standardized collection and genotyping methods will be required to clarify these findings.

\section{Apical membrane antigen 1}

Multiple lines of evidence indicate that polymorphisms in the P. falciparum AMA1 domain I result from selective pressures exerted by protective host immune responses [86]. In a study in Papua New Guinea, a pattern of geographical diversity and the particular substitutions found were suggestive of strong constraints acting on the evolution of AMA1 at the population level. In addition, differences between the sequences of AMA1 domain I from symptomatic and asymptomatic 
infections implicate AMA1 as a possible determinant of the morbidity associated with a particular $P$. falciparum strain [86].

\section{Erythrocyte binding antigen 175}

Studies on the distribution of EBA-175 genotypes suggest that this gene plays a role in different clinical outcomes. Genomic studies of two P. falciparum strains, namely FCR-3 and CAMP, revealed two highly dimorphic segments in region III, which is located in the central part of the gene [87]. Dimorphism is referred to as the F-fragment in the FCR-3 strain and the C-fragment in the CAMP strain. In a study, the CAMP $(\mathrm{C})$ and FCR-3(F-) genotypes of the EBA-175 were encountered in both symptomatic and asymptomatic patients, but the FCR-3 genotype predominated regardless of clinical status and the sampling period since the FCR-3(F-) genotypes were simply more prevalent in the region [22]. However, the prevalence of mixed C-/F- infection was far higher in symptomatic than in asymptomatic children. This study showed that mixed C-/F- infection is associated with clinical malaria and may have therapeutic implications [32].

\section{Virulence genes}

An important aspect of $P$. falciparum virulence is the ability of infected erythrocytes to sequester and obstruct the microvasculature of different organs. Cytoadhesion to endothelial cells is mediated by electron-dense elevations of the parasite membrane referred to as knobs. Knobs consist predominantly of the knob-associated histidine-rich protein (KAHRP), which cluster on the cytoplasmic face of the knob membrane [88]. KAHRP is required for knob formation and has also been used as a marker because of its role in pathology [89]. In one study, three different alleles (340 bp, $370 \mathrm{bp}$ and 400 bp) were found in mild cases, but only two forms (340 bp and $370 \mathrm{bp}$ ) were observed in severe cases [90]. Studies on the association of these KAHRP alleles with severity need to be extended to asymptomatic malaria.

Many gene expression studies in P. falciparum have focused on the diverse var gene family, encoding various forms of erythrocyte membrane protein 1 (PfEMP1), which is involved in cytoadherence of RBCs (red blood cells) to endothelial cells [91]. Switching of PfEMP1 isoforms through differential expression of members of the var multigene family is thought to facilitate evasion of the host immune response [91,92]. Most var genes fall into three major groups: var A, var B, and var C. Emerging evidence suggests that specific expression of these groups has clinical relevance and that major differences in the transcription profile of var gene expression may differentiate disease severity [33,93]. For example, var group $C$ transcript levels were increased in asymptomatic cases, whereas transcripts of var group A and $B$ were abundant in patients with severe malaria [33]. Another study reported that $P$. falciparum isolates from cerebral malaria patients are significantly more likely to transcribe var genes with DBL $\alpha 1$-like domains, characteristic of Group A and Group B/A (an intermediate group of var gene), than the isolates from patients with non-severe hyperparasitaemia (i.e., high parasitaemia with no symptoms or signs of severe disease) [94]. Recent studies on var gene expression and malaria severity have yielded conflicting results $[33,93,95,96]$. These studies are complicated by extensive variation in the var gene transcription and the phenotypes displayed by circulating parasites, which may be different to those sequestered, as in severe malaria. Therefore, comparing the repertoire of genomic and expressed var genes with a particular malaria outcome will be helpful to understand the role of this gene family in asymptomatic malaria.

\section{Other factors that influence malaria outcomes}

The formation of rosettes may influence the severity of malaria by causing distinct patterns of sequestration with different pathogenic consequences [68]. Parasite toxins such as glycosylphosphatidylinositol (GPI) anchors and haemozoin have been proposed to drive shock-like syndromes during infection $[97,98]$. However, the roles of these factors have not been reported in asymptomatic cases.

Intraleucocytic malaria pigment found in neutrophils is suggested to be a better indicator of disease severity than the peripheral parasite count $[99,100]$. Nguyen et al. [100] first reported an increase in the proportion of malaria-pigment containing neutrophils and monocytes in severe malaria patients. Later, Amodu et al. [99] confirmed that there was an unambiguous rise in the proportion of malaria pigment-containing neutrophils as severity increases across a range of disease outcomes, from uninfected to severe malaria cases. Amodu et al. [99] also reported that the proportion of pigment-containing monocytes did not differ significantly between mild malaria, asymptomatic malaria, and no malaria groups; however, the severe (cerebral) malaria group had a higher median value than the other three groups. Further, a case-control investigation [101] expanded and validated the finding that monocytes and neutrophils are markers of disease severity, but unfortunately asymptomatic malaria cases were not assayed in this study.

\section{Role of human host factors in clinical outcomes}

Studies on the association of the roles of host factors such as genes of the immune system, RBC polymorphisms or disorders, circulating levels of immunoglobulins and cytokines, and pregnancy should not be limited 
only to symptomatic malaria, but also include asymptomatic malaria. To date this has usually not been the case; the role of host factors in asymptomatic malaria largely remains a field ripe for inquiry.

\section{Polymorphisms of immunologically relevant genes}

Significant correlations between SNPs (single nucleotide polymorphisms) in regulatory or coding regions and severe malaria have been reported for several immunologically relevant genes, including cluster for differentiation-40 ligand (CD40L), Fc gamma receptor II (Fc $\gamma \mathrm{RII})$, complement receptor 1 (CR1), tumor necrosis factor $\alpha$ (TNF- $\alpha$ ), interleukins $-4,-12$, and -13 (IL-4, IL-12, IL13), intracellular cell adhesion molecule-1 (ICAM-1), CD-36, platelet endothelial cell adhesion molecule-1 (PECAM-1), toll-like receptor (TLR), and mannose binding lectin 2 (MBL2)[102-115]. However, the association between a particular SNP and response to infection is highly dependent on ethnic background, i.e., an association demonstrated for one ethnic group may not be the same for a population that differs both in genetic background as well as frequency of exposure to infection [116]. Thus, disease correlation with certain SNPs inferred from studies of African or Caucasian populations may or may not yield the same results in ethnically divergent or admixed populations. For example, allelic and genotypic frequencies of interleukin-10 (IL-10-1087 $\mathrm{A} / \mathrm{G}$ ) and in IL-4-590 C/T polymorphisms have been reported to vary based on inter-ethnic differences [117]. A study conducted in Gabon reported no statistically significant association between MBL, TNF $\alpha-308$, or NOS2 polymorphisms and asymptomatic malaria [118]. However, this may not be true for other geographical regions of the world. Studies on the genetic differences between populations may provide a better understanding of the role of these genes. A summary of the variants and polymorphisms of the erythrocytic and immunologically relevant genes of the human system involved in malaria susceptibility and resistance is given in Additional file 3.

\section{RBC polymorphisms or disorders}

Several RBC polymorphisms, like G6PD deficiency $[118,119]$, haemoglobin variants $[120,121]$, ABO blood group antigen [122], ovalocytosis [123], and polymorphisms in complement receptor 1 [124], have been shown to provide at least some protection against severe malaria, suggesting the possibility of coevolution between parasite and host. Such protective roles are much less clear for mild malaria and for asymptomatic malaria [125].

However, research on G6PD polymorphisms has expanded in the last decade to include a range of disease outcomes. For example, G6PD A heterozygosity in females confers protection against all forms of malaria, including the asymptomatic form [118]. The mechanism of this protection may be because the parasite in G6PD $\mathrm{A}^{-}$heterozygous female host must cycle between G6PD $\mathrm{A}^{-}$and G6PD wild type erythrocytes and may fail to adapt to the G6PD A- environment [126].

The global distribution of $\mathrm{ABO}$ blood group antigens reflects natural selection by various pathogens. There is strong evidence that $\mathrm{O}$ blood group provides protection against malaria by a mechanism of reduced rosetting and sequestration [127], while other reports have found an association between presence of blood group A with higher incidence of severe malaria $[128,129]$. A study that associated the blood groups of children with malaria disease outcome, found a high prevalence of asymptomatic malaria in children with the blood group $\mathrm{O}$ antigen, when compared with those without this antigen [121]. This study suggested that the blood group $O$ provides protection against clinical forms of malaria. However, the association in this study was weak $(p=$ $0.05)$. Further evidence for such protective effects must not only consider the distribution of blood groups, but also other explanations, such as the anti-rosette formation effect associated with blood group antigens [130].

\section{Immunity due to circulating levels of immunoglobulins and cytokines}

Different clinical outcomes during malaria infection may be due to differences in the host immunity level. Acquisition of natural immunity to malaria has been observed in high and stable (i.e., intense and constant over months and years) malaria transmission areas. This immunity acquired due to repeated exposure reduces the risk of both severe and mild malaria. Therefore, asymptomatic malaria could be a consequence of natural immunity. However, in low transmission areas in South America clinical immunity is found to develop in underexposed individuals, resulting in asymptomatic malaria [50]. Hence, it could be possible that a person in a low transmission area develops immunity faster because: (1) there is less antigenic diversity circulating in the regions and/or (2) there are less infections to overwhelm the immune response $[131,132]$.

Malaria infection induces polyclonal immunoglobulin production the proportion of which determines protection against the blood stages of $P$. falciparum. Evidence suggests that antibody-dependent mechanisms play an important role in the reduction of parasitaemia and this alleviates clinical symptoms, as demonstrated by the passive transfer of hyper-immune immunoglobulin G (IgG) $[133,134]$. Among the various IgG isotypes, cytophilic antibodies IgG1 and IgG3 have been consistently correlated with uncomplicated malaria and even offer protection, while IgG4 does not protect against malaria 
[135-139]. Infections have also been associated with elevations in total IgE, with higher levels detected in cerebral P. falciparum malaria than in uncomplicated mild malaria [140,141]. The role of anti-parasite specific IgE is, however, controversial. Some studies have observed higher antimalarial IgE levels and functional activity in asymptomatic and uncomplicated malaria groups than in severe or cerebral malaria groups [30]. Additionally, high anti-P. falciparum IgE levels have been associated with a reduced risk of developing clinical malaria [142]. This supports a theory of IgE antibodies having a role in protection against disease. Results from others studies suggest that high levels of parasite-specific IgE are observed in patients with severe malaria, which indicates a putative role in pathogenesis [143-146].

One of the most challenging issues with studying malaria immunology is that individuals at risk for malaria infections are typically at risk for other parasitic or non-parasitic diseases. Distilling the immunological response induced by malaria apart from other infectious diseases is not straightforward. For example, co-infection of Plasmodium parasites with soil transmitted helminthes or Hepatitis B Virus (HBV) has been reported in several studies. Helminth infections may alter susceptibility to clinical malaria by changing the T-helper1/ T-helper2 (Th1/Th2) balance $[147,148]$, thereby affecting immunoglobulin levels. These findings are based on the assumption that helminth infections induce a strong and highly polarized immune response [149], which has been suggested to help facilitate the acquisition of immunity to malaria. In contrast, $\mathrm{HBV}$ when co-infected with Plasmodium influences the malaria burden by stimulating an increased inflammatory response. Plasmodium-infected individuals with HBV infection were more likely to be asymptomatic with lower levels of parasitaemia and a decreased inflammatory cytokine profile [150]. Thus, the host's immune system is modified by other co-infecting organisms thereby complicating our understanding of malaria clinical outcome.

Age is considered one of the most important factors that correlate with protective immunity in malaria endemic areas. Infections among non-immune individuals invariably result in clinical symptoms, and often lead to death in young children if untreated [11]. Young children are most susceptible to malaria infections and disease onset as they have not yet acquired clinical immunity. In endemic areas, adults and older children have a lower prevalence of malaria infection and lower incidence of clinical malaria [151]. These individuals acquire immunity from severe malaria episodes during childhood [7] and therefore as an adolescent or adult they are more likely to develop uncomplicated or asymptomatic malaria than severe malaria [6]. Severe cases are typically found in adults if they are non- immune or have not encountered malaria before $[152,153]$.

In adult individuals, the acquired immunity or protection which is thought to keep their malaria asymptomatic or uncomplicated could be due to increased frequency of both type 1 and type 2 cytokine-producing $\mathrm{T}$ cells [154]. Cytokines are involved in both protection from, as well as the pathogenesis of, malaria infections. Elevated levels of circulating cytokines such as interleukin-6 (IL-6), IL-12, IL-1, and IL-10, as well as high circulating levels of TNF- $\alpha$, all appear to have some correlation with the severity of the disease [111]. In falciparum malaria, cytokines may stimulate beneficial immunological responses by inducing acute phase responses, inhibiting parasite growth, and clearing vascular parasites and debris. Inflammatory responses mediated by interferon gamma (IFN- $\gamma$ ) in the interleukin 12 (IL-12) and 18 (IL-18) dependent manner, seems to be crucial for the control of parasitaemia through the induction of tumor necrosis factor (TNF) and the enhanced release of anti-parasitic reactive nitrogen and oxygen radicals. TNF and INF- $\gamma$ stimulate neutrophils in order to increase parasite destruction [155].

\section{Pregnancy}

Pregnant women are more susceptible to malaria infection, a phenomenon especially apparent during the first pregnancy [156]. In successive pregnancies, a decrease in intensity of infection has been observed and attributed to the acquisition of antibodies against variant surface antigens (VSA) such as PfEMP-1 (P. falciparum Erythrocyte Membrane Protein-1), rifins, and stevors. These antigens are expressed on parasitized RBCs infecting the placenta and are most commonly referred to as Variant Surface Antigens of Pregnancy Associated Malaria (VSA-PAM) [157,158]. The immunological relevance of these biological factors associated with asymptomatic malaria needs to be established. Studies on the evaluation of cytokine and growth factor in asymptomatic pregnant women showed an association between increased plasma concentrations of IL-10 and G-CSF [159].

\section{Treatment and management of asymptomatic malaria}

Drug therapy has often been linked to the development of gametocytaemia, as environmental pressure caused by the targeted destruction of the asexual stage parasites stimulates the production sexual stage parasites (reviewed in [160]). Though this may be true, there is also mounting evidence, found in studies like Bousema et al. [161], which suggests that the production of gametocytes may be unrelated to drug therapy. In this study, Bousema et al. [161] investigated gametocytaemia in a 
cohort of untreated, asymptomatic children (less than five years old). This study reported that despite a lack of treatment, a significant proportion of these children had quantifiable gametocytes. Therefore, asymptomatic individuals have the potential to develop gametocytes even in the absence of drug therapy and this pool may serve as reservoir of disease transmission.

Since the transmission of malaria parasites from humans to mosquitoes requires the presence of gametocytes, any strategy that interferes with the development or persistence of gametocytes should help to interrupt transmission. In most malaria endemic areas, the majority of parasite carriers are asymptomatic [162] and these carriers typically do not seek medical treatment. Therefore, asymptomatic individuals carrying gametocytes remain available as a reservoir for transmission by mosquitoes, contributing to the persistence of malaria transmission within local populations $[14,161]$.

The identification and management of asymptomatic carriers has become a new and increasingly important challenge for malaria control programs. One challenge, in particular, is to reform the development of novel anti-malarial drugs to include those that explicitly target transmissible sexual stages. At the present, the majority of anti-malarial drug treatments on the market target the asexual blood stage of $P$. falciparum. Treatment regimens containing artemisinin and/or its derivatives are reported to lower gametocyte carriage, and reduced infectivity among treated individuals [163-165]. Artemisinin combination therapy (ACT), which is advocated as the first-line of anti-malarial treatment, and has been reported to be efficient in reducing even submicroscopic levels of gametocytes $[55,164,166,167]$. Intermittent preventive treatment (IPT), the administration of a full course of an anti-malarial treatment to a population at risk at specified time points regardless of the infection status of individuals, has been proposed as a method of treatment for asymptomatic individuals to reduce transmission of disease. Artemether-lumefantrine, an ACT drug currently available on the market, has been suggested as a candidate for IPT treatment of asymptomatic carriers [168]. The short half-life of lumefantrine makes it an ideal treatment strategy because of concerns for developing resistance to ACT. Pharmacokinetic determinants of resistance selection indicate that this drug has a considerably shorter "window of selection," when compared to other artemisinin companion drugs, such as mefloquine [169].

Apart from selection for drug resistance, there is an additional risk of the persistence of submicroscopic gametocytes even after treatment, allowing for posttreatment malaria transmission [166]. Primaquine, a widely used drug for the treatment of $P$. vivax malaria, actively clears submicroscopic $P$. falciparum gametocytes [170-172], but the possible haemolytic effects of primaquine in relation to G6PD deficiencies must be considered before marketing this drug for the treatment of gametocytes. Reports indicate that artesunate (a derivative of artemisinin) may predominantly inhibit gametocyte development, while primaquine may accelerate its clearance [172]. However primaquine, when given in combination with sulphadoxine-pyrimethamine and artesunate, was found to be both safe and highly efficient in clearing P. falciparum gametocytes and asexual parasites detected by microscopy [173] as well as submicroscopic gametocytes [174]. As part of surveillance and control strategies for malaria, the systematic diagnosis or identification and treatment of asymptomatic carriers could reduce the pool of parasites available for the infection of mosquitoes.

The transmissibility of submicroscopic parasites within asymptomatic malaria infections may help to drive the persistence of malaria within endemic regions. The use of antimalarial drug treatment (particularly ACTs), in combination with insecticide treated nets (ITNs), longlasting insecticidal nets (LLINs), and indoor residual spraying (IRS) is perhaps the most aggressive method for reducing the malaria burden in endemic regions. A recent study by Aregawi et al. [175] using ACT in combination with ITNs/LLINs and IRS demonstrated a 76\% reduction in slide positivity for all age groups over a 4 year intensive intervention effort. Singling out the mosquito vector by undertaking comprehensive entomological and ecological studies is necessary for fully understanding malaria transmission dynamics, i.e. the identification of vector breeding and resting sites, the impact of climate change and temperature variation on vector survival and capacity, and also insecticide resistance.

\section{Perspectives and future research}

The history of research on asymptomatic malaria dates back to 1900 when Robert Koch first identified such cases in a study among patients in Papua New Guinea [176]. Yet, asymptomatic malaria has rarely been a major research focus. Since individuals with asymptomatic malaria present with no symptoms, there are inconsistencies in defining, difficulties in diagnosing, and a general lack of urgency to investigate this particular disease outcome. In some sense, asymptomatic malaria has become the "forgotten" malaria, although recently asymptomatic malaria has become accepted as a major hurdle for malaria elimination, as infected hosts serve as silent reservoirs. The treatment of asymptomatic carriers as part of routine surveillance strategies has the potential to make a significant contribution to the reduction of malaria in endemic regions. 
Scaling up efforts to improve the characterization of asymptomatic malaria in endemic regions and establishing a standard case definition for this malaria disease outcome is a priority. To help facilitate this in field studies, longitudinal active case detection methods, improved epidemiology questionnaires, and advanced epidemiological modeling must become universal components in all epidemiological studies. Concerted efforts should also be directed towards the development of highly sensitive, cheap and easily obtained rapid diagnostic detection kits, which can be used to detect parasitaemia at submicroscopic densities [177]. Identifying the extent of the problem is a major challenge.

Secondarily, the underlying causes of asymptomatic malaria must be fully investigated. It is important to expand beyond the traditional association and correlation analyses to include more comprehensive molecular methods. If detection efforts are improved, then it will be possible to discriminate between the host and parasite roles in asymptomatic infection. Consequently, parasite population diversity studies will become more thorough, the association of parasite virulence genes will become more relevant, and the malaria field will have a better sense of how to interpret and manage different disease outcomes. Importantly, information on host genetics and immune responses in association with asymptomatic malaria are severely lacking, but could provide a wealth of knowledge on the management of disease and the roles that they play in mounting different responses to infection.

\section{Additional material}

Additional file 1: Diagnostic criteria for defining malaria patients as asymptomatic. The list represents a snap-shot of some of the studies of asymptomatic infections world-wide.

Additional file 2: List of $P$. falciparum genes reported to be associated with different clinical outcomes of malaria. (DOC $78 \mathrm{~kb}$ ). Additional file 3: List of human genes reported to be associated with different clinical outcomes of malaria. A. Human gene polymorphisms B. Human blood disorders.

\section{Acknowledgements}

The authors would like to thank Dr. Surendra Kumar Prajapati for suggestions during the preparation of the manuscript, and Dr. Steven Sullivan for proof reading and editing. We are also thankful to the previous NIMR Director-In-Charge, Dr. V.K. Dua, for his support. DDL, NN and JMC were supported by grant 5D43TW007884-05 "Promotion of Plasmodium Research and Training in India" and PL was supported by a U.S. Global Health Postdoctoral Scientist Fellowship 3D43TW007884-03S1, both from the National Institutes of Health/Fogarty International Center. The content is solely the responsibility of the authors and does not necessarily represent the official views of the Fogarty International Center or the National Institutes of Health. JMC was also supported by 1U19A1089676-01 "Center for the Study of Complex Malaria in India" from the National Institutes of Health/National Institute of Allergy and Infectious Diseases.

\section{Author details}

'National Institute of Malaria Research, Indian Council of Medical Research, Sector 8, Dwarka, New Delhi 110 077, India. ${ }^{2}$ Center for Genomics and Systems Biology, Department of Biology, New York University, 12 Waverly Place, New York, NY 10003, USA. ${ }^{3}$ Department of Zoology, Panjab University, Chandigarh 160014, India. ${ }^{4}$ Department of Biotechnology, Panjab University, Chandigarh 160014, India.

\section{Authors' contributions}

DDL and PS mined the literature. DDL, PLS, NN, VLS, RCS and JMC wrote the manuscript. HJ contributed to initial discussions and planning. All authors with the exception of $\mathrm{HJ}$ (deceased) read and approved the final manuscript.

\section{Competing interests}

The authors declare that they have no competing interests.

Received: 15 July 2011 Accepted: 31 January 2012

Published: 31 January 2012

\section{References}

1. WHO: Annual Report Geneva: World Health Organization; 2008.

2. McGregor IA: Demographic effects of malaria with special reference to the stable malaria of Africa. West Afr Med J 1960, 81:260-265.

3. Marsh K, Forster D, Waruiru C, Mwangi I, Winstanley M, Marsh V, Newton C, Winstanley P, Warn P, Peshu N, Pasvol G, Snow R: Indicators of lifethreatening malaria in African children. N Engl J Med 1995, 332:1399-1404.

4. WHO: Severe falciparum malaria. World Health Organization, Communicable Diseases Cluster. Trans R Soc Trop Med Hyg 2000, 94(Suppl 1):S1-S90.

5. Snow RW, Omumbo JA, Lowe B, Molyneux CS, Obiero JO, Palmer A, Weber MW, Pinder M, Nahlen B, Obonyo C, Newbold C, Gupta S, Marsh K: Relation between severe malaria morbidity in children and level of Plasmodium falciparum transmission in Africa. Lancet 1997, 349:1650-1654.

6. Grobusch MP, Kremsner PG: Uncomplicated malaria. Curr Top Microbiol Immunol 2005, 295:83-104.

7. Gupta S, Snow RW, Donnelly CA, Marsh K, Newbold C: Immunity to noncerebral severe malaria is acquired after one or two infections. Nat Med 1999, 5:340-343.

8. Bottius E, Guanzirolli A, Trape JF, Rogier C, Konate L, Druilhe P: Malaria: even more chronic in nature than previously thought; evidence for subpatent parasitaemia detectable by the polymerase chain reaction. Trans R Soc Trop Med Hyg 1996, 90:15-19.

9. Trape JF, Zoulani A, Quinet MC: Assessment of the incidence and prevalence of clinical malaria in semi-immune children exposed to intense and perennial transmission. Am J Epidemiol 1987, 126:193-201.

10. Daubersies P, Sallenave-Sales S, Magne S, Trape JF, Contamin H, Fandeur T, Rogier C, Mercereau-Puijalon O, Druilhe P: Rapid turnover of Plasmodium falciparum populations in asymptomatic individuals living in a high transmission area. Am J Trop Med Hyg 1996, 54:18-26.

11. Day KP, Marsh K: Naturally acquired immunity to Plasmodium falciparum. Immunol Today 1991, 12:A68-A71.

12. Trape JF, Rogier $C$, Konate L, Diagne $N$, Bouganali $H$, Canque B, Legros $F$, Badji A, Ndiaye G, Ndiaye P, Brahimi K, Faye O, Druilhe P, Da Silva LP: The Dielmo project: a longitudinal study of natural malaria infection and the mechanisms of protective immunity in a community living in a holoendemic area of Senegal. Am J Trop Med Hyg 1994, 51:123-137.

13. Roper MH, Torres RS, Goicochea CG, Andersen EM, Guarda JS, Calampa C, Hightower AW, Magill AJ: The epidemiology of malaria in an epidemic area of the Peruvian Amazon. Am J Trop Med Hyg 2000, 62:247-256.

14. Alves FP, Gil LH, Marrelli MT, Ribolla PE, Camargo EP, Da Silva LH: Asymptomatic carriers of Plasmodium sp. as infection source for malaria vector mosquitoes in the Brazilian Amazon. J Med Entomol 2005, 42:777-779.

15. Roshanravan B, Kari E, Gilman RH, Cabrera L, Lee E, Metcalfe J, Calderon M, Lescano AG, Montenegro SH, Calampa C, Vinetz JM: Endemic malaria in the Peruvian Amazon region of lquitos. Am J Trop Med Hyg 2003, 69:45-52.

16. Branch O, Casapia WM, Gamboa DV, Hernandez JN, Alava FF, Roncal N, Alvarez E, Perez EJ, Gotuzzo E: Clustered local transmission and asymptomatic Plasmodium falciparum and Plasmodium vivax malaria 
infections in a recently emerged, hypoendemic Peruvian Amazon community. Malar J 2005, 4:27.

17. Cerutti C Jr, Boulos M, Coutinho AF, Hatab Mdo C, Falqueto A, Rezende HR, Duarte AM, Collins W, Malafronte RS: Epidemiologic aspects of the malaria transmission cycle in an area of very low incidence in Brazil. Malar J 2007, 6:33.

18. Fugikaha E, Fornazari PA, Penhalbel Rde S, Lorenzetti A, Maroso RD, Amoras JT, Saraiva AS, Silva RU, Bonini-Domingos CR, Mattos LC, Rossit AR, Cavasini CE, Machado RL: Molecular screening of Plasmodium sp. asymptomatic carriers among transfusion centers from Brazilian Amazon region. Rev Inst Med Trop Sao Paulo 2007, 49:1-4.

19. Cucunuba ZM, Guerra AP, Rahirant SJ, Rivera JA, Cortes LJ, Nicholls RS: Asymptomatic Plasmodium sp. infection in Tierralta, Colombia. Mem Inst Oswaldo Cruz 2008, 103:668-673.

20. Harris I, Sharrock WW, Bain LM, Gray KA, Bobogare A, Boaz L, Lilley K, Krause D, Vallely A, Johnson ML, Gatton ML, Shanks GD, Cheng Q: A large proportion of asymptomatic Plasmodium infections with low and submicroscopic parasite densities in the low transmission setting of Temotu Province, Solomon Islands: challenges for malaria diagnostics in an elimination setting. Malar J 2010, 9:254.

21. Alves FP, Durlacher RR, Menezes MJ, Krieger H, Silva LH, Camargo EP: High prevalence of asymptomatic Plasmodium vivax and Plasmodium falciparum infections in native Amazonian populations. Am J Trop Med Hyg 2002, 66:641-648.

22. Suarez-Mutis MC, Cuervo P, Leoratti FM, Moraes-Avila SL, Ferreira AW, Fernandes O, Coura JR: Cross sectional study reveals a high percentage of asymptomatic Plasmodium vivax infection in the Amazon Rio Negro area, Brazil. Rev Inst Med Trop Sao Paulo 2007, 49:159-164.

23. Scuracchio P, Vieira SD, Dourado DA, Bueno LM, Colella R, RamosSanchez EM, Lima GF, Inoue J, Sanchez MC, Di Santi SM: Transfusiontransmitted malaria: case report of asymptomatic donor harboring Plasmodium malariae. Rev Inst Med Trop Sao Paulo 2011, 53:55-59.

24. Vinetz JM, Li J, McCutchan TF, Kaslow DC: Plasmodium malariae infection in an asymptomatic 74-year-old Greek woman with splenomegaly. N Engl J Med 1998, 338:367-371.

25. Rojo-Marcos G, Cuadros-Gonzalez J, Gete-Garcia L, Gomez-Herruz P, LopezRubio M, Esteban-Gutierrez G: Plasmodium ovale infection: description of 16 cases and a review. Enferm Infecc Microbiol Clin 2011, 29:204-208.

26. Coura JR, Suarez-Mutis M, Ladeia-Andrade S: A new challenge for malaria control in Brazil: asymptomatic Plasmodium infection-a review. Mem Inst Oswaldo Cruz 2006, 101:229-237.

27. de Mast Q, Syafruddin D, Keijmel S, Olde Riekerink T, Deky O, Asih PB, Swinkels DW, van der Ven AJ: Increased serum hepcidin and alterations in blood iron parameters associated with asymptomatic $P$. falciparum and $P$. vivax malaria. Haematologica 2010, 95:1068-1074.

28. Leoratti FM, Durlacher RR, Lacerda MV, Alecrim MG, Ferreira AW, Sanchez MC, Moraes SL: Pattern of humoral immune response to Plasmodium falciparum blood stages in individuals presenting different clinical expressions of malaria. Malar J 2008, 7:186.

29. Males S, Gaye O, Garcia A: Long-term asymptomatic carriage of Plasmodium falciparum protects from malaria attacks: a prospective study among Senegalese children. Clin Infect Dis 2008, 46:516-522.

30. Duarte J, Deshpande P, Guiyedi V, Mecheri S, Fesel C, Cazenave PA, Mishra GC, Kombila M, Pied S: Total and functional parasite specific lgE responses in Plasmodium falciparum-infected patients exhibiting different clinical status. Malar J 2007, 6:1.

31. dalla Martha RC, Tada MS, Ferreira RG, da Silva LH, Wunderlich G: Microsatellite characterization of Plasmodium falciparum from symptomatic and non-symptomatic infections from the Western Amazon reveals the existence of non-symptomatic infection-associated genotypes. Mem Inst Oswaldo Cruz 2007, 102:293-298.

32. Toure FS, Bisseye C, Mavoungou E: Imbalanced distribution of Plasmodium falciparum EBA-175 genotypes related to clinical status in children from Bakoumba, Gabon. Clin Med Res 2006, 4:7-11.

33. Rottmann M, Lavstsen T, Mugasa JP, Kaestli M, Jensen AT, Muller D, Theander T, Beck HP: Differential expression of var gene groups is associated with morbidity caused by Plasmodium falciparum infection in Tanzanian children. Infect Immun 2006, 74:3904-3911.

34. Eke RA, Chigbu LN, Nwachukwu W: High Prevalence of asymptomatic Plasmodium infection in a Suburb of Aba Town, Nigeria. Ann Afr Med 2006, 5:42-45.
35. Dal-Bianco MP, Koster KB, Kombila UD, Kun JF, Grobusch MP, Ngoma GM, Matsiegui PB, Supan C, Salazar CL, Missinou MA, Issifou S, Lell B, Kremsner P. High prevalence of asymptomatic Plasmodium falciparum infection in Gabonese adults. AmJTrop Med Hyg 2007, 77:939-942.

36. de Andrade AL, Martelli CM, Oliveira RM, Arias JR, Zicker F, Pang L: High prevalence of asymptomatic malaria in gold mining areas in Brazil. Clin Infect Dis 1995, 20:475.

37. Abdel-Latif MS, Dietz K, Issifou S, Kremsner PG, Klinkert MQ: Antibodies to Plasmodium falciparum rifin proteins are associated with rapid parasite clearance and asymptomatic infections. Infect Immun 2003, 71:6229-6233.

38. Boutlis CS, Tjitra T, Maniboey H, Misukonis MA, Saunders JR, Suprianto S, Weinberg JB, Anstey NM: Nitric oxide production and mononuclear cell nitric oxide synthase activity in malaria-tolerant Papuan adults. Infect Immun 2003, 71:3682-3689.

39. Carter R, Mendis KN, Roberts D: Spatial targeting of interventions against malaria. Bull World Health Organ 2000, 78:1401-1411.

40. Mackinnon MJ, Gunawardena DM, Rajakaruna J, Weerasingha S, Mendis KN, Carter R: Quantifying genetic and nongenetic contributions to malarial infection in a Sri Lankan population. Proc Natl Acad Sci USA 2000, 97:12661-12666.

41. Krajden S, Panisko DM, Tobe B, Yang J, Keystone JS: Prolonged infection with Plasmodium falciparum in a semi-immune patient. Trans $R$ Soc Trop Med Hyg 1991, 85:731-732.

42. Babiker HA, Abdel-Muhsin AM, Ranford-Cartwright LC, Satti G, Walliker D: Characteristics of Plasmodium falciparum parasites that survive the lengthy dry season in eastern Sudan where malaria transmission is markedly seasonal. Am J Trop Med Hyg 1998, 59:582-590.

43. Vafa M, Troye-Blomberg M, Anchang J, Garcia A, Migot-Nabias F: Multiplicity of Plasmodium falciparum infection in asymptomatic children in Senegal: relation to transmission, age and erythrocyte variants. Malar J 2008, 7:17.

44. Le Port A, Cot M, Etard JF, Gaye O, Migot-Nabias F, Garcia A: Relation between Plasmodium falciparum asymptomatic infection and malaria attacks in a cohort of Senegalese children. Malar J 2008, 7:193.

45. Greenwood BM, Bradley AK, Greenwood AM, Byass P, Jammeh K, Marsh K, Tulloch S, Oldfield FS, Hayes R: Mortality and morbidity from malaria among children in a rural area of The Gambia, West Africa. Trans $R$ Soc Trop Med Hyg 1987, 81:478-486.

46. Smith T, Charlwood JD, Kihonda J, Mwankusye S, Billingsley P, Meuwissen J, Lyimo E, Takken W, Teuscher T, Tanner M: Absence of seasonal variation in malaria parasitaemia in an area of intense seasonal transmission. Acta Trop 1993, 54:55-72.

47. Tomson G: Immunity in malaria. Trans R Soc Trop Med Hyg 1933, 26:483-503.

48. Camargo LM, Noronha E, Salcedo JM, Dutra AP, Krieger H, da Pereira Silva $L H$, Camargo EP: The epidemiology of malaria in Rondonia (Western Amazon region, Brazil): study of a riverine population. Acta Trop 1999, 72:1-11.

49. Camargo EP, Alves F, da Pereira Silva LH: Symptomless Plasmodium vivax infections in native Amazonians. Lancet 1999, 353:1415-1416.

50. Torres KJ, Clark EH, Hernandez JN, Soto-Cornejo KE, Gamboa D, Branch OH: Antibody response dynamics to the Plasmodium falciparum conserved vaccine candidate antigen, merozoite surface protein-1 C-terminal $19 \mathrm{kD}$ (MSP1-19 kD), in Peruvians exposed to hypoendemic malaria transmission. Malar J 2008, 7:173.

51. Weiss GE, Clark EH, Li S, Traore B, Kayentao K, Ongoiba A, Hernandez JN, Doumbo OK, Pierce SK, Branch OH, Crompton PD: A positive correlation between atypical memory $\mathrm{B}$ cells and Plasmodium falciparum transmission intensity in cross-sectional studies in Peru and Mali. PLOS One 2011, 6:e15983.

52. Schneider P, Bousema JT, Gouagna LC, Otieno S, van de Vegte-Bolmer M, Omar SA, Sauerwein RW: Submicroscopic Plasmodium falciparum gametocyte densities frequently result in mosquito infection. Am J Trop Med Hyg 2007, 76:470-474.

53. Paul RE, Bonnet $\mathrm{S}$, Boudin C, Tchuinkam T, Robert V: Aggregation in malaria parasites places limits on mosquito infection rates. Infect Genet Evol 2007, 7:577-586.

54. Drakeley CJ, Secka I, Correa S, Greenwood BM, Targett GA: Host haematological factors influencing the transmission of Plasmodium falciparum gametocytes to Anopheles gambiae s.s. mosquitoes. Trop Med Int Health 1999, 4:131-138. 
55. Targett G, Drakeley C, Jawara M, von Seidlein L, Coleman R, Deen J, Pinder M, Doherty T, Sutherland C, Walraven G, Milligan P: Artesunate reduces but does not prevent posttreatment transmission of Plasmodium falciparum to Anopheles gambiae. J Infect Dis 2001, 183:1254-1259.

56. Nwakanma D, Kheir A, Sowa M, Dunyo S, Jawara M, Pinder M, Milligan P, Walliker D, Babiker HA: High gametocyte complexity and mosquito infectivity of Plasmodium falciparum in the Gambia. Int J Parasitol 2008, 38:219-227.

57. Boudin C, Olivier M, Molez JF, Chiron JP, Ambroise-Thomas P: High human malarial infectivity to laboratory-bred Anopheles gambiae in a village in Burkina Faso. Am J Trop Med Hyg 1993, 48:700-706.

58. Hogh B, Gamage-Mendis A, Butcher GA, Thompson R, Begtrup K, Mendis C, Enosse SM, Dgedge M, Barreto J, Eling W, Sinden RE: The differing impact of chloroquine and pyrimethamine/sulfadoxine upon the infectivity of malaria species to the mosquito vector. Am J Trop Med Hyg 1998, 58:176-182.

59. Nedelman J: Gametocytaemia and infectiousness in falciparum malaria: observations and models. Adv Dis Vector Res 1989, 6:59-89.

60. Hallett RL, Dunyo S, Ord R, Jawara M, Pinder M, Randall A, Alloueche A, Walraven G, Targett GA, Alexander N, Sutherland CJ: Chloroquine/ sulphadoxine-pyrimethamine for gambian children with malaria: transmission to mosquitoes of multidrug-resistant Plasmodium falciparum. PLoS Clin Trials 2006, 1:e15.

61. Meerman L, Ord R, Bousema JT, van Niekerk M, Osman E, Hallett R, Pinder M, Walraven G, Sutherland CJ: Carriage of chloroquine-resistant parasites and delay of effective treatment increase the risk of severe malaria in Gambian children. J Infect Dis 2005, 192:1651-1657.

62. Price $R$, Nosten $F$, Simpson JA, Luxemburger $C$, Phaipun $L$, ter Kuile $F$, van Vugt $M$, Chongsuphajaisiddhi T, White NJ: Risk factors for gametocyte carriage in uncomplicated falciparum malaria. AmJTrop Med Hyg 1999, 60:1019-1023.

63. Jeffery GM, Young MD, Eyles DE: The treatment of Plasmodium falciparum infection with chloroquine, with a note on infectivity to mosquitoes of primaquine- and pyrimethamine-treated cases. Am J Hyg 1956, 64:1-11.

64. Smalley ME, Sinden RE: Plasmodium falciparum gametocytes: their longevity and infectivity. Parasitology 1977, 74:1-8.

65. Pethleart A, Prajakwong S, Suwonkerd W, Corthong B, Webber R, Curtis C: Infectious reservoir of Plasmodium infection in Mae Hong Son Province, north-west Thailand. Malar J 2004, 3:34.

66. Gouagna LC, Ferguson HM, Okech BA, Killeen GF, Kabiru EW, Beier JC, Githure J, Yan G: Plasmodium falciparum malaria disease manifestations in humans and transmission to Anopheles gambiae: a field study in Western Kenya. Parasitology 2004, 128:235-243.

67. Gouagna LC, Okech BA, Kabiru EW, Killeen GF, Obare P, Ombonya S, Bier JC, Knols BG, Githure Jl, Yan G: Infectivity of Plasmodium falciparum gametocytes in patients attending rural health centres in western Kenya. East Afr Med J 2003, 80:627-634.

68. Miller LH, Baruch DI, Marsh K, Doumbo OK: The pathogenic basis of malaria. Nature 2002, 415:673-679.

69. White NJ, Chapman D, Watt G: The effects of multiplication and synchronicity on the vascular distribution of parasites in falciparum malaria. Trans R Soc Trop Med Hyg 1992, 86:590-597.

70. Silamut K, Phu NH, Whitty C, Turner GD, Louwrier K, Mai NT, Simpson JA, Hien T, White NJ: A quantitative analysis of the microvascular sequestration of malaria parasites in the human brain. Am J Pathol 1999, 155:395-410

71. Njama-Meya D, Kamya MR, Dorsey G: Asymptomatic parasitaemia as a risk factor for symptomatic malaria in a cohort of Ugandan children. Trop Med Int Health 2004, 9:862-868.

72. Maina RN, Walsh D, Gaddy C, Hongo G, Waitumbi J, Otieno L, Jones D, Ogutu BR: Impact of Plasmodium falciparum infection on haematological parameters in children living in Western Kenya. Malar J 2010, 9(Suppl 3): S4.

73. Jeremiah ZA, Uko EK: Depression of platelet counts in apparently healthy children with asymptomatic malaria infection in a Nigerian metropolitan city. Platelets 2007, 18:469-471.

74. Marsh K, Howard RJ: Antigens induced on erythrocytes by P. falciparum: expression of diverse and conserved determinants. Science 1986, 231:150-153.
75. Giha HA, Theander TG, Staalso T, Roper C, Elhassan IM, Babiker H, Satti GM, Arnot DE, Hviid L: Seasonal variation in agglutination of Plasmodium falciparum-infected erythrocytes. Am J Trop Med Hyg 1998, 58:399-405.

76. Gupta S, Day KP: A strain theory of malaria transmission. Parasitol Today 1994, 10:476-481.

77. Bendixen M, Msangeni HA, Pedersen BV, Shayo D, Bodker R: Diversity of Plasmodium falciparum populations and complexity of infections in relation to transmission intensity and host age: a study from the Usambara Mountains, Tanzania. Trans R Soc Trop Med Hyg 2001, 95:143-148.

78. Robert F, Ntoumi F, Angel G, Candito D, Rogier C, Fandeur T, Sarthou JL, Mercereau-Puijalon O: Extensive genetic diversity of Plasmodium falciparum isolates collected from patients with severe malaria in Dakar, Senegal. Trans R Soc Trop Med Hyg 1996, 90:704-711.

79. Smith T, Felger I, Beck HP, Tanner M: Consequences of multiple infection with Plasmodium falciparum in an area of high endemicity. Parassitologia 1999, 41:247-250.

80. Amodu OK, Adeyemo AA, Ayoola OO, Gbadegesin RA, Orimadegun AE, Akinsola AK, Olumese PE, Omotade OO: Genetic diversity of the msp-1 locus and symptomatic malaria in south-west Nigeria. Acta Trop 2005, 95:226-232.

81. Ariey F, Hommel D, Le Scanf C, Duchemin JB, Peneau C, Hulin A, Sarthou JL, Reynes JM, Fandeur T, Mercereau-Puijalon O: Association of severe malaria with a specific Plasmodium falciparum genotype in French Guiana. J Infect Dis 2001, 184:237-241.

82. Amodu OK, Oyedeji SI, Ntoumi F, Orimadegun AE, Gbadegesin RA, Olumese PE, Omotade OO: Complexity of the msp2 locus and the severity of childhood malaria, in south-western Nigeria. Ann Trop Med Parasitol 2008, 102:95-102.

83. Engelbrecht F, Felger I, Genton B, Alpers M, Beck HP: Plasmodium falciparum: malaria morbidity is associated with specific merozoite surface antigen 2 genotypes. Exp Parasitol 1995, 81:90-96.

84. Al-Yaman F, Genton B, Taraika J, Anders R, Alpers MP: Cellular immunity to merozoite surface protein 2 (FC27 and 3D7) in Papua New Guinean children. Temporal variation and relation to clinical and parasitological status. Parasite Immunol 1997, 19:207-214.

85. Cortes A, Mellombo M, Benet A, Lorry K, Rare L, Reeder JC: Plasmodium falciparum: distribution of msp2 genotypes among symptomatic and asymptomatic individuals from the Wosera region of Papua New Guinea. Exp Parasitol 2004, 106:22-29.

86. Cortes A, Mellombo M, Mueller I, Benet A, Reeder JC, Anders RF: Geographical structure of diversity and differences between symptomatic and asymptomatic infections for Plasmodium falciparum vaccine candidate AMA1. Infect Immun 2003, 71:1416-1426.

87. Sim BK: EBA-175: an erythrocyte-binding ligand of Plasmodium falciparum. Parasitol Today 1995, 11:213-217.

88. Pologe LG, Pavlovec A, Shio H, Ravetch JV: Primary structure and subcellular localization of the knob-associated histidine-rich protein of Plasmodium falciparum. Proc Natl Acad Sci USA 1987, 84:7139-7143.

89. Bhutani N, Ranjit MR, Yameen M, Singh N, Dev V, Pillai CR, Ansari MA Sharma YD: Genetic diversity among field isolates of Plasmodium falciparum in India. Curr Sci 1998, 75:160-163.

90. Ranjit MR, Das A, Das BP, Das BN, Dash BP, Chhotray GP: Distribution of Plasmodium falciparum genotypes in clinically mild and severe malaria cases in Orissa, India. Trans R Soc Trop Med Hyg 2005, 99:389-395.

91. Su XZ, Heatwole VM, Wertheimer SP, Guinet F, Herrfeldt JA, Peterson DS, Ravetch JA, Wellems TE: The large diverse gene family var encodes proteins involved in cytoadherence and antigenic variation of Plasmodium falciparum-infected erythrocytes. Cell 1995, 82:89-100.

92. Smith JD, Chitnis CE, Craig AG, Roberts DJ, Hudson-Taylor DE, Peterson DS, Pinches R, Newbold Cl, Miller LH: Switches in expression of Plasmodium falciparum var genes correlate with changes in antigenic and cytoadherent phenotypes of infected erythrocytes. Cell 1995, 82:101-110.

93. Kaestli M, Cockburn IA, Cortes A, Baea K, Rowe JA, Beck HP: Virulence of malaria is associated with differential expression of Plasmodium falciparum var gene subgroups in a case-control study. J Infect Dis 2006, 193:1567-1574.

94. Kyriacou HM, Stone GN, Challis RJ, Raza A, Lyke KE, Thera MA, Kone AK, Doumbo OK, Plowe CV, Rowe JA: Differential va gene transcription in Plasmodium falciparum isolates from patients with cerebral malaria compared to hyperparasitaemia. Mol Biochem Parasitol 2006, 150:211-218. 
95. Kirchgatter $K$, del Portillo HA: Association of severe noncerebral Plasmodium falciparum malaria in Brazil with expressed PfEMP1 DBL1 alpha sequences lacking cysteine residues. Mol Med 2002, 8:16-23.

96. Bull PC, Berriman M, Kyes S, Quail MA, Hall N, Kortok MM, Marsh K, Newbold Cl: Plasmodium falciparum variant surface antigen expression patterns during malaria. PLOS Pathog 2005, 1:e26.

97. Schofield L, Mueller I: Clinical immunity to malaria. Curr Mol Med 2006, 6:205-221.

98. Yazdani SS, Mukherjee P, Chauhan VS, Chitnis CE: Immune responses to asexual blood-stages of malaria parasites. Curr Mol Med 2006, 6:187-203.

99. Amodu OK, Adeyemo AA, Olumese PE, Gbadegesin RA: Intraleucocytic malaria pigment and clinical severity of malaria in children. Trans $R$ Soc Trop Med Hyg 1998, 92:54-56.

100. Lyke KE, Diallo DA, Dicko A, Kone A, Coulibaly D, Guindo A, Cissoko Y, Sangare L, Coulibaly S, Dakouo B, Taylor TE, Doumbo OK, Plowe CV: Association of intraleukocytic Plasmodium falciparum malaria pigment with disease severity, clinical manifestations, and prognosis in severe malaria. Am J Trop Med Hyg 2003, 69:253-259.

101. Nguyen PH, Day N, Pram TD, Ferguson DJ, White NJ: Intraleucocytic malaria pigment and prognosis in severe malaria. Trans $R$ Soc Trop Med Hyg 1995, 89:200-204.

102. McGuire W, Hill AV, Allsopp CE, Greenwood BM, Kwiatkowski D: Variation in the TNF-alpha promoter region associated with susceptibility to cerebral malaria. Nature 1994, 371:508-510.

103. Fernandez-Reyes D, Craig AG, Kyes SA, Peshu N, Snow RW, Berendt AR, Marsh K, Newbold Cl: A high frequency African coding polymorphism in the N-terminal domain of ICAM-1 predisposing to cerebral malaria in Kenya. Hum Mol Genet 1997, 6:1357-1360.

104. Hill, Weatherall : In Malaria: Parasite Biology Pathogenesis and Protection Washington: ASM; 1998.

105. Kun JF, Klabunde J, Lell B, Luckner D, Alpers M, May J, Meyer C, Kremsner PG: Association of the ICAM-1Kilifi mutation with protection against severe malaria in Lambarene, Gabon. Am J Trop Med Hyg 1999, 61:776-779.

106. Kikuchi M, Looareesuwan S, Ubalee R, Tasanor O, Suzuki F, Wattanagoon Y, Na-Bangchang K, Kimura A, Aikawa M, Hirayama K: Association of adhesion molecule PECAM-1/CD31 polymorphism with susceptibility to cerebral malaria in Thais. Parasitol Int 2001, 50:235-239.

107. Shi YP, Nahlen BL, Kariuki S, Urdahl KB, McElroy PD, Roberts JM, Lal AA: Fcgamma receptor lla (CD32) polymorphism is associated with protection of infants against high-density Plasmodium falciparum infection. VII. Asembo Bay Cohort Project. J Infect Dis 2001, 184:107-111.

108. Sabeti P, Usen S, Farhadian S, Jallow M, Doherty T, Newport M, Pinder M, Ward R, Kwiatkowski D: CD40L association with protection from severe malaria. Genes Immun 2002, 3:286-291.

109. Omi K, Ohashi J, Patarapotikul J, Hananantachai H, Naka I, Looareesuwan S, Tokunaga $\mathrm{K}$ : CD36 polymorphism is associated with protection from cerebral malaria. Am J Hum Genet 2003, 72:364-374.

110. Gyan BA, Goka B, Cvetkovic JT, Kurtzhals JL, Adabayeri V, Perlmann H, Lefvert AK, Akanmori BD, Troye-Blomberg M: Allelic polymorphisms in the repeat and promoter regions of the interleukin- 4 gene and malaria severity in Ghanaian children. Clin Exp Immunol 2004, 138:145-150.

111. Lyke KE, Burges R, Cissoko Y, Sangare L, Dao M, Diarra I, Kone A, Harley R, Plowe CV, Doumbo OK, Sztein MB: Serum levels of the proinflammatory cytokines interleukin-1 beta (IL-1beta), IL-6, IL-8, IL-10, tumor necrosis factor alpha, and IL-12(p70) in Malian children with severe Plasmodium falciparum malaria and matched uncomplicated malaria or healthy controls. Infect Immun 2004, 72:5630-5637.

112. Verra F, Luoni G, Calissano C, Troye-Blomberg M, Perlmann P, Perlmann H, Arca B, Sirima BS, Konate A, Coluzzi M, Kwiatkowski D, Modiano D: IL4-589 $\mathrm{C} / \mathrm{T}$ polymorphism and IgE levels in severe malaria. Acta Trop 2004, 90:205-209.

113. Leoratti FM, Farias L, Alves FP, Suarez-Mutis MC, Coura JR, Kalil J, Camargo EP, Moraes SL, Ramasawmy R: Variants in the toll-like receptor signaling pathway and clinical outcomes of malaria. J Infect Dis 2008, 198:772-780.

114. Sinha S, Mishra SK, Sharma S, Patibandla PK, Mallick PK, Sharma SK, Mohanty S, Pati SS, Mishra SK, Ramteke BK, Bhatt R, Joshi H, Dash AP, Ahuja RC, Awasthi S, Venkatesh V, Habib S: Polymorphisms of TNFenhancer and gene for FcgammaRlla correlate with the severity of falciparum malaria in the ethnically diverse Indian population. Malar J 2008, 7:13.

115. Boldt AB, Messias-Reason IJ, Lell B, Issifou S, Pedroso ML, Kremsner PG, Kun JF: Haplotype specific-sequencing reveals MBL2 association with asymptomatic Plasmodium falciparum infection. Malar J 2009, 8:97.

116. Kwiatkowski D: Genetic susceptibility to malaria getting complex. Curr Opin Genet Dev 2000, 10:320-324.

117. Vafa M, Maiga B, Berzins K, Hayano M, Bereczky S, Dolo A, Daou M, Arama C, Kouriba B, Farnert A, Doumbo OK, Troye-Blomberg M: Associations between the IL-4-590 T allele and Plasmodium falciparum infection prevalence in asymptomatic Fulani of Mali. Microbes Infect 2007, 9:1043-1048

118. Mombo LE, Ntoumi F, Bisseye C, Ossari S, Lu CY, Nagel RL, Krishnamoorthy R: Human genetic polymorphisms and asymptomatic Plasmodium falciparum malaria in Gabonese schoolchildren. Am J Trop Med Hyg 2003, 68:186-190.

119. Ruwende C, Khoo SC, Snow RW, Yates SN, Kwiatkowski D, Gupta S, Warn P, Allsopp CE, Gilbert SC, Peschu N, Newbold Cl, Greenwood BM, Marsh K, Hill AVS: Natural selection of hemi- and heterozygotes for G6PD deficiency in Africa by resistance to severe malaria. Nature 1995, 376:246-249.

120. Modiano D, Luoni G, Sirima BS, Simpore J, Verra F, Konate A, Rastrelli E, Olivieri A, Calissano C, Paganotti GM, D'Urbano L, Sanou I, Sawadogo A, Modiano G, Coluzzi M: Haemoglobin C protects against clinical Plasmodium falciparum malaria. Nature 2001, 414:305-308.

121. Chotivanich K, Udomsangpetch R, Pattanapanyasat K, Chierakul W Simpson J, Looareesuwan S, White N: Hemoglobin E: a balanced polymorphism protective against high parasitemias and thus severe $P$. falciparum malaria. Blood 2002, 100:1172-1176.

122. Hill AV: Malaria resistance genes: a natural selection. Trans $R$ Soc Trop Med Hyg 1992, 86:225-226, 232.

123. Genton B, al-Yaman F, Mgone CS, Alexander N, Paniu MM, Alpers MP, Mokela D: Ovalocytosis and cerebral malaria. Nature 1995, 378:564-565

124. Cockburn IA, Mackinnon MJ, O'Donnell A, Allen SJ, Moulds JM, Baisor M Bockarie M, Reeder JC, Rowe JA: A human complement receptor 1 polymorphism that reduces Plasmodium falciparum rosetting confers protection against severe malaria. Proc Natl Acad Sci USA 2004, 101:272-277.

125. Migot-Nabias F, Pelleau S, Watier L, Guitard J, Toly C, De Araujo C, Ngom Ml, Chevillard C, Gaye O, Garcia A: Red blood cell polymorphisms in relation to Plasmodium falciparum asymptomatic parasite densities and morbidity in Senegal. Microbes Infect 2006, 8:2352-2358.

126. Usanga EA, Luzzatto L: Adaptation of Plasmodium falciparum to glucose 6-phosphate dehydrogenase-deficient host red cells by production of parasite-encoded enzyme. Nature 1985, 313:793-795.

127. Rowe JA, Handel IG, Thera MA, Deans AM, Lyke KE, Kone A, Diallo DA, Raza A, Kai O, Marsh K, Plowe CV, Doumbo OK, Moulds JM: Blood group O protects against severe Plasmodium falciparum malaria through the mechanism of reduced rosetting. Proc Natl Acad Sci USA 2007, 104:17471-17476.

128. Fischer PR, Boone P: Short report: severe malaria associated with blood group. Am J Trop Med Hyg 1998, 58:122-123.

129. Lell B, May J, Schmidt-Ott RJ, Lehman LG, Luckner D, Greve B, Matousek P, Schmid D, Herbich K, Mockenhaupt FP, Meyer CG, Bienzle U, Kremsner PG: The role of red blood cell polymorphisms in resistance and susceptibility to malaria. Clin Infect Dis 1999, 28:794-799.

130. Barragan A, Kremsner PG, Wahlgren M, Carlson J: Blood group A antigen is a coreceptor in Plasmodium falciparum rosetting. Infect Immun 2000, 68:2971-2975.

131. Branch OH, Takala S, Kariuki S, Nahlen BL, Kolczak M, Hawley W, Lal AA: Plasmodium falciparum genotypes, low complexity of infection, and resistance to subsequent malaria in participants in the Asembo Bay Cohort Project. Infect Immun 2001, 69:7783-7792.

132. Holt RA, Subramanian GM, Halpern A, Sutton GG, Charlab R, Nusskern DR, Wincker P, Clark AG, Ribeiro JM, Wides R, Salzberg SL, Loftus B, Yandell M, Majoros WH, Rusch DB, Lai Z, Kraft CL, Abril JF, Anthouard V, Arensburger P, Atkinson PW, Baden $H$, de Berardinis V, Baldwin D, Benes V, Biedler J, Blass C, Bolanos R, Boscus D, Barnstead M, Cai S, Center A, Chaturverdi K, Christophides GK, Chrystal MA, Clamp M, Cravchik A, Curwen V, Dana A, Delcher A, Dew I, Evans CA, Flanigan M, Grundschober-Freimoser A, Friedli L, Gu Z, Guan P, Guigo R, Hillenmeyer ME, Hladun SL, Hogan JR, 
Hong YS, Hoover J, Jaillon O, Ke Z, Kodira C, Kokoza E, Koutsos A, Letunic I, Levitsky A, Liang Y, Lin JJ, Lobo NF, Lopez JR, Malek JA, Mclntosh TC, Meister S, Miller J, Mobarry C, Mongin E, Murphy SD, O'Brochta DA, Pfannkoch C, Qi R, Regier MA, Remington K, Shao H, Sharakhova MV, Sitter CD, Shetty J, Smith TJ, Strong R, Sun J, Thomasova D, Ton LQ, Topalis $P$, Tu Z, Unger MF, Walenz B, Wang A, Wang J, Wang M, Wang X, Woodford KJ, Wortman JR, Wu M, Yao A, Zdobnov EM, Zhang H, Zhao Q, Zhao S, Zhu SC, Zhimulev I, Coluzzi M, della Torre A, Roth CW, Louis C, Kalush F, Mural RJ, Myers EW, Adams MD, Smith HO, Broder S, Gardner MJ, Fraser CM, Birney E, Bork P, Brey PT, Venter JC, Weissenbach J, Kafatos FC, Collins FH, Hoffman SL: The genome sequence of the malaria mosquito Anopheles gambiae. Science 2002, 298:129-149.

133. Plebanski M, Hill AV: The immunology of malaria infection. Curr Opin Immunol 2000, 12:437-441.

134. Bouharoun-Tayoun $H$, Attanath $P$, Sabchareon A, Chongsuphajaisiddhi T, Druilhe P: Antibodies that protect humans against Plasmodium falciparum blood stages do not on their own inhibit parasite growth and invasion in vitro, but act in cooperation with monocytes. J Exp Med 1990, 172:1633-1641.

135. Groux H, Gysin J: Opsonization as an effector mechanism in human protection against asexual blood stages of Plasmodium falciparum: functional role of IgG subclasses. Res Immunol 1990, 141:529-542.

136. Sarthou JL, Angel G, Aribot G, Rogier C, Dieye A, Toure Balde A, Diatta B, Seignot $P$, Roussilhon $C$ : Prognostic value of anti-Plasmodium falciparumspecific immunoglobulin G3, cytokines, and their soluble receptors in West African patients with severe malaria. Infect Immun 1997, 65:3271-3276

137. Tangteerawatana P, Krudsood S, Chalermrut K, Looareesuwan S, Khusmith S: Natural human IgG subclass antibodies to Plasmodium falciparum blood stage antigens and their relation to malaria resistance in an endemic area of Thailand. Southeast Asian J Trop Med Public Health 2001, 32:247-254

138. Tangteerawatana P, Montgomery SM, Perlmann H, Looareesuwan S, TroyeBlomberg M, Khusmith S: Differential regulation of IgG subclasses and IgE antimalarial antibody responses in complicated and uncomplicated Plasmodium falciparum malaria. Parasite Immunol 2007, 29:475-483.

139. Lucchi NW, Tongren JE, Jain V, Nagpal AC, Kauth CW, Woehlbier U, Bujard H, Dash AP, Singh N, Stiles JK, Udhayakumar V: Antibody responses to the merozoite surface protein-1 complex in cerebral malaria patients in India. Malar J 2008, 7:121.

140. Desowitz RS: Plasmodium-specific immunoglobulin E in sera from an area of holoendemic malaria. Trans R Soc Trop Med Hyg 1989, 83:478-479.

141. Luty AJ, Mayombo J, Lekoulou F, Mshana R: Immunologic responses to soluble exoantigens of Plasmodium falciparum in Gabonese children exposed to continuous intense infection. AmJTrop Med Hyg 1994, 51:720-729.

142. Farouk SE, Dolo A, Bereczky S, Kouriba B, Maiga B, Farnert A, Perlmann H, Hayano M, Montgomery SM, Doumbo OK, Troye-Blomberg M: Different antibody- and cytokine-mediated responses to Plasmodium falciparum parasite in two sympatric ethnic tribes living in Mali. Microbes Infect 2005, 7:110-117.

143. Perlmann H, Helmby H, Hagstedt M, Carlson J, Larsson PH, TroyeBlomberg M, Perlmann P: IgE elevation and IgE anti-malarial antibodies in Plasmodium falciparum malaria: association of high lgE levels with cerebral malaria. Clin Exp Immunol 1994, 97:284-292.

144. Perlmann P, Bjorkman A: Malaria research: host-parasite interactions and new developments in chemotherapy, immunology and vaccinology. Curr Opin Infect Dis 2000, 13:431-443.

145. Perlmann P, Perlmann H, ElGhazali G, Blomberg MT: IgE and tumor necrosis factor in malaria infection. Immunol Lett 1999, 65:29-33.

146. Perlmann P, Perlmann H, Looareesuwan S, Krudsood S, Kano S, Matsumoto Y, Brittenham G, Troye-Blomberg M, Aikawa M: Contrasting functions of $\lg G$ and $\lg E$ antimalarial antibodies in uncomplicated and severe Plasmodium falciparum malaria. Am J Trop Med Hyg 2000, 62:373-377.

147. Nacher M, Singhasivanon P, Silachamroon U, Treeprasertsuk S, Vannaphan S, Traore B, Gay F, Looareesuwan S: Helminth infections are associated with protection from malaria-related acute renal failure and jaundice in Thailand. Am J Trop Med Hyg 2001, 65:834-836.

148. Druilhe P, Tall A, Sokhna C: Worms can worsen malaria: towards a new means to roll back malaria? Trends Parasitol 2005, 21:359-362.
149. Maizels RM, Balic A, Gomez-Escobar N, Nair M, Taylor MD, Allen JE: Helminth parasites-masters of regulation. Immunol Rev 2004, 201:89-116.

150. Andrade BB, Santos CJ, Camargo LM, Souza-Neto SM, Reis-Filho A, Clarencio J, Mendonca VR, Luz NF, Camargo EP, Barral A, Silva AA, BarralNetto M: Hepatitis B infection is associated with asymptomatic malaria in the Brazilian Amazon. PLoS One 2011, 6:e19841.

151. Djimde AA, Doumbo OK, Traore O, Guindo AB, Kayentao K, Diourte $Y$, Niare-Doumbo S, Coulibaly D, Kone AK, Cissoko Y, Tekete M, Fofana B, Dicko A, Diallo DA, Wellems TE, Kwiatkowski D, Plowe CV: Clearance of drug-resistant parasites as a model for protective immunity in Plasmodium falciparum malaria. AmJTrop Med Hyg 2003, 69:558-563.

152. Baird JK, Masbar S, Basri H, Tirtokusumo S, Subianto B, Hoffman SL: Agedependent susceptibility to severe disease with primary exposure to Plasmodium falciparum. J Infect Dis 1998, 178:592-595.

153. Schwartz E, Sadetzki S, Murad H, Raveh D: Age as a risk factor for severe Plasmodium falciparum malaria in nonimmune patients. Clin Infect Dis 2001, 33:1774-1777.

154. Winkler S, Willheim M, Baier K, Schmid D, Aichelburg A, Graninger W, Kremsner PG: Frequency of cytokine-producing $T$ cells in patients of different age groups with Plasmodium falciparum malaria. $J$ Infect Dis 1999, 179:209-216.

155. Kumaratilake LM, Ferrante A, Jaeger T, Rzepczyk CM: Effects of cytokines, complement, and antibody on the neutrophil respiratory burst and phagocytic response to Plasmodium falciparum merozoites. Infect Immun 1992, 60:3731-3738.

156. Desai M, ter Kuile FO, Nosten F, McGready R, Asamoa K, Brabin B, Newman RD: Epidemiology and burden of malaria in pregnancy. Lancet Infect Dis 2007, 7:93-104.

157. Rogerson SJ, Wijesinghe RS, Meshnick SR: Host immunity as a determinant of treatment outcome in Plasmodium falciparum malaria. Lancet Infect Dis 2010, 10:51-59.

158. Fried M, Nosten F, Brockman A, Brabin BJ, Duffy PE: Maternal antibodies block malaria. Nature 1998, 395:851-852.

159. Wilson NO, Bythwood T, Solomon W, Jolly P, Yatich N, Jiang Y, Shuaib F, Adjei AA, Anderson W, Stiles JK: Elevated levels of IL-10 and G-CSF associated with asymptomatic malaria in pregnant women. Infect Dis Obstet Gynecol 2010, 2010.

160. Dixon MW, Thompson J, Gardiner DL, Trenholme KR: Sex in Plasmodium: a sign of commitment. Trends Parasitol 2008, 24:168-175.

161. Bousema JT, Gouagna LC, Drakeley CJ, Meutstege AM, Okech BA, Akim IN, Beier JC, Githure Jl, Sauerwein RW: Plasmodium falciparum gametocyte carriage in asymptomatic children in western Kenya. Malar J 2004, 3:18.

162. Smith T, Schellenberg JA, Hayes R: Attributable fraction estimates and case definitions for malaria in endemic areas. Stat Med 1994, 13:2345-2358.

163. von Seidlein $L$, Bojang $K$, Jones $P$, Jaffar $S$, Pinder $M$, Obaro $S$, Doherty $T$, Haywood M, Snounou G, Gemperli B, Gathmann I, Royce C, McAdam K, Greenwood B: A randomized controlled trial of artemether/benflumetol, a new antimalarial and pyrimethamine/sulfadoxine in the treatment of uncomplicated falciparum malaria in African children. Am J Trop Med Hyg 1998, 58:638-644.

164. Sutherland CJ, Ord R, Dunyo S, Jawara M, Drakeley CJ, Alexander N, Coleman R, Pinder M, Walraven G, Targett GA: Reduction of malaria transmission to Anopheles mosquitoes with a six-dose regimen of coartemether. PLoS Med 2005, 2:e92.

165. Price RN, Nosten F, Luxemburger C, ter Kuile FO, Paiphun L, Chongsuphajaisiddhi T, White NJ: Effects of artemisinin derivatives on malaria transmissibility. Lancet 1996, 347:1654-1658.

166. Bousema JT, Schneider P, Gouagna LC, Drakeley CJ, Tostmann A, Houben R, Githure JI, Ord R, Sutherland CJ, Omar SA, Sauerwein RW: Moderate effect of artemisinin-based combination therapy on transmission of Plasmodium falciparum. J Infect Dis 2006, 193:1151-1159.

167. Drakeley CJ, Jawara M, Targett GA, Walraven G, Obisike U, Coleman R, Pinder $M$, Sutherland $C$ J: Addition of artesunate to chloroquine for treatment of Plasmodium falciparum malaria in Gambian children causes a significant but short-lived reduction in infectiousness for mosquitoes. Trop Med Int Health 2004, 9:53-61.

168. Ogutu B, Tiono AB, Makanga M, Premji Z, Gbadoe AD, Ubben D, Marrast AC, Gaye O: Treatment of asymptomatic carriers with artemetherlumefantrine: an opportunity to reduce the burden of malaria? Malar J 2010, 9:30. 
169. Stepniewska K, White NJ: Pharmacokinetic determinants of the window of selection for antimalarial drug resistance. Antimicrob Agents Chemother 2008, 52:1589-1596.

170. Butcher GA: Antimalarial drugs and the mosquito transmission of Plasmodium. Int J Parasitol 1997, 27:975-987.

171. Taylor WR, White NJ: Antimalarial drug toxicity: a review. Drug Saf 2004, 27:25-61.

172. Pukrittayakamee S, Chotivanich K, Chantra A, Clemens R, Looareesuwan S, White NJ: Activities of artesunate and primaquine against asexual- and sexual-stage parasites in falciparum malaria. Antimicrob Agents Chemother 2004, 48:1329-1334.

173. Weerasinghe KL, Galappaththy G, Fernando WP, Wickremasinghe DR, Faizal HM, Wickremasinghe AR: A safety and efficacy trial of artesunate, sulphadoxine-pyrimethamine and primaquine in $P$. falciparum malaria. Ceylon Med J 2002, 47:83-85.

174. Shekalaghe S, Drakeley C, Gosling R, Ndaro A, van Meegeren M, Enevold A, Alifrangis M, Mosha F, Sauerwein R, Bousema T: Primaquine clears submicroscopic Plasmodium falciparum gametocytes that persist after treatment with sulphadoxine-pyrimethamine and artesunate. PLoS One 2007, 2:e1023.

175. Aregawi MW, Ali AS, Al-mafazy AW, Molteni F, Katikiti S, Warsame M, Njau RJ, Komatsu R, Korenromp E, Hosseini M, Low-Beer D, Bjorkman A, D'Alessandro U, Coosemans M, Otten M: Reductions in malaria and anaemia case and death burden at hospitals following scale-up of malaria control in Zanzibar, 1999-2008. Malar J 2011, 10:46.

176. Harrison G: Mosquitoes, malaria and man: a history of hostilities since 1880, John Murray, London. 1978, 172-174.

177. Coleman RE, Maneechai N, Rachapaew N, Kumpitak C, Soyseng V, Miller RS, Thimasarn K, Sattabongkot J: Field evaluation of the ICT Malaria Pf/Pv immunochromatographic test for the detection of asymptomatic malaria in a Plasmodium falciparum/vivax endemic area in Thailand. AmJTrop Med Hyg 2002, 66:379-383.

\section{doi:10.1186/1475-2875-11-29}

Cite this article as: Laishram et al:: The complexities of malaria disease manifestations with a focus on asymptomatic malaria. Malaria Journal 2012 11:29.

\section{Submit your next manuscript to BioMed Central and take full advantage of:}

- Convenient online submission

- Thorough peer review

- No space constraints or color figure charges

- Immediate publication on acceptance

- Inclusion in PubMed, CAS, Scopus and Google Scholar

- Research which is freely available for redistribution

Submit your manuscript at www.biomedcentral.com/submit

C Biomed Central 